\title{
The Implementation Of Full Day School At Senior High School In Buleleng Regency Year 2019/2020
}

\author{
Prasetya, G.H. ${ }^{1}$, Nitiasih, P.K.를 ${ }^{2}$ Budiarta, L .G. R. ${ }^{3}$
}

${ }^{123}$ English Language Education, Ganesha University of Education, Bali, Indonesia

\author{
A R T I C L E I N F 0 \\ Article history: \\ Received 5 June 2020 \\ Received in revised \\ Form 01 July 2020 \\ Accepted 18 August \\ 2020 \\ Available online 3 \\ October 2020 \\ Keywords: \\ advantages and \\ disadvantages, full day \\ school, teachers'
}

\begin{abstract}
A B S T R A C T
This study aimed to 1) investigate students' perception on the implementation of the full day school in SMAN 1 Singaraja and SMAN 4 Singaraja 2) investigate teachers' perception on the implementation of the full day school in SMAN 1 Singaraja and SMAN 4 Singaraja 3) investigate strength and weakness on the implementation of the full day school in SMAN 1 Singaraja and SMAN 4 Singaraja. The design used in this study was descriptive qualitative. The subjects of this study were 11th-grade students and teachers from SMAN 1 Singaraja and SMAN 4 Singaraja. The result showed that 1) the students' perception on the implementation of Full Day School in SMAN 4 Singaraja and SMAN 1 Singaraja are categorized as positive. 2) the teachers' perception on the implementation of Full Day School in SMAN 4 Singaraja and SMAN 1 Singaraja are categorized as positive. 3) the strengths of the full-day school were developing teacher's creativity in terms of teaching and developing students' creativity in terms of affective, cognitive and psychomotor 4) The weakness the students could be bored because of additional hours of learning.
\end{abstract}

\section{Introduction}

Full day school is a learning system that is fully implemented, where many children's activities are carried out at school rather than at home. The basic concept of the full day school is Integrated Curriculum and Integrated Activity which is a form of learning that is expected to form a highly intellectual child (student) who can combine aspects of skills and knowledge with a good attitude Rahim (2018). The government always improves better education for the young generation to have a better future and also a good character. The synergy of comprehensive components in the instructional process at full day school has influenced the building of the students' character effectively and efficiently Benawa et al., (2017). There are more challenges for the government in Indonesia to make good education in this era to make the students avoid negative things such as gang fights, drugs, and free sex. The government tries to optimize character education again, one way is to implement a full-day school, where schools increase student learning hours in school by adding character values through extra-curricular activities and religious activities Nurkholis et al. (2018). In education the government has to deal with technology and also the system of education should be better to get the attention of the students to learn and enjoy with learning program in the school to get the knowledge, the reasons of the full day school are avoiding those negative things and develop the character of students in Indonesia, it is based on the latest curriculum that is applied in Indonesia, namely Curriculum 2013 (K-13) which has purposed to build the character of the students in Indonesia and also make them more active in learning, to be reliable innovative and also preparing to face the challenges in globalization era Kemendikbud (2013). From curriculum 2013 (K-13) the government wants to develop the education and the reach the goal of one of the purposes of K-13 that is character-building Indonesia for the students through the Minister of Education and Culture Mudjahir Effendy add a new program and regulation in education from curriculum 2013 (K-13) called full day school Kemendikbud (2013). The history of the full day school in Indonesia already exist around the 1990s it called boarding school. The full day school has a longer time in the school for study and avoids the students for negative things that they can do, the time is around 8 hours in school to do something that can give them more benefit or knowledge in education.

Corresponding author.

E-mail addresses: gdeprasetya@gmail.com (Prasetya), titiekjegeg@gmail.com (Nitiasih, P.K.), budiartarahayu@gmail.com (Budiarta, L .G. R.) 


\section{Full Day School}

According to Kemendikbud (2013), full day school is an 8 hours program in a day start from Monday until Friday, it is started since 12 June 2017 and this program requires creativity and innovation from the teacher. According to Rahmah (2017) full day school is a school that focuses on the quality, quantity of the learning process, and the quality of students' input, all activities of the educational program happen in the school (full day school with characteristics of the integrated activity and integrated curriculum). Basuki (2008) also stated that full day school is a program that half part of the time used for programs learning that is informal, relax, fun, for students in learning and it requires creativity and innovation from the teacher.

Full day school program is one way to solve the crime that causes by teenager or students because full day school is purpose also for character building. According to Yusuf (2017) Full day school is a program with the strategy of shortening the time outside the school with strategies learners get an extra hour to education, which designed to the process of education and learning. The idea of full day school is very feasible to minimize the negative influence of the home environment and the community outside the school. Hidayanti (2017) said that full day school is one program from the government that can solve and overcome the problems, a full day school can improve and develop students' character. In its implementation, a full day school based on a balancing program between cognitive, emotional, social, and spiritual abilities is considered an excellent program, because it makes student learning time effective and maximizes the full potential of students. Others think that full day school can make students overlystressed due to the burden of learning (Heru, Jatimi, Fiddaroini, Syamsudin, 2019).

The system of full day school the students have to study in the school for five days from Monday to Friday with 8 hours for study and have two part times for taking a rest. In Indonesia, full day school has been implemented since 2017. In Bali, full day school has been implemented for around 3 years. There are some schools that already implementing the full day school, especially in Singaraja Sub District, Buleleng Regency, they are SMAN 1 Singaraja, SMAN 4 Singaraja, SMAN 3 Singaraja, SMA N 1 Sukasada, and SMKN 1 Sukasada. SMAN 1 Singaraja and SMAN 4 Singaraja are the schools which have been implemented full day school and are considered as a model for other schools in Buleleng Regency. Both of those schools start the lesson from 07.00 AM until 04.00 PM and have two part times for rest which have 30 minutes in each part-time for rest and have five effective days to study in school from Monday until Friday.

In the implementation of a full day school program in those schools, the teacher did not give their students homework because all the exercises from the teacher will be explained and discussed in the class. The implementation of full day school has many pros and cons, both from the teachers and the students. Based on the pre-interview, the teachers who have a pro opinion about full day school answered that they have more time at home due to they only need to teach at school for five days, and they have two days off at home. Meanwhile, in contrast, the teacher feels tired of teaching the students at school in about 8 hours. Looking at the students' side, based on the pre-interview, from the students who pros about full day school, they feel happy because they can study with their friends in a longer time at school rather than staying at home and doing nothing, while in cons, the student feels less concentrate because they feel tired in studying. From these opinions based on the pre-interview result, it is necessary to know more about how the implementation of full day school. Later, this thesis hopefully can be a source for another senior high school who want to implement full day school program.

\section{Review from Previous Studies}

Several studies have been done by the previous researchers that are related to this topic, the studies as follows: Hardianti (2018) conducted a study on analyzing the teachers' and students' perception towards the implementation of five days of school (full day school). Her study aims to find teachers' perceptions toward the implementation of a full day school in SMN 1 Pinrang. This research uses a descriptive qualitative approach, her data collection technique consists of three, namely: observation, interviews, and documentation. In addition, the data sources used are primary data and secondary data. Primary data consists of 6 teachers and 10 students while secondary data is other supporting documents. Based on the results of $t$ her study, she found that the first is the teacher's perception of the application of full day school in general, the teacher agreed with the application in SMK 1 Pinrang because SMKN is a vocational school that uses a long time to conduct vocational practice and student behavior can be supervised during the school environment. The second is about students' perceptions of the application of full day school at 1 Pinrang Vocational School in general, she found that the students did not agree because they felt tired, sleepy and bored so that class activities were not conducive and students' learning motivation decreased and students' rest periods were erratic. The contribution of this research gives information about the teachers' and students' perceptions toward the implementation of full day school. 
The difference of this research compare with research from the researcher is the subject is vocational high school.

A study conducted by Triyono (2018) which analyzed the academic civitas perception to 5 days of school implementation for Senior High School and equivalent. This study aimed to understand academics civitas perception of the policy implementation effectiveness in terms of academic and psychological aspects, from the policy of the minister and culture No.23/2017 that arranged the school day began from Monday until Friday. This research is done by using a mixed-method with a sequential explanatory as model data analysis. The result of the study found that, from all the indicators it can be concluded that the teachers' and students' perception during 5 days school implementation is good, except for being an indicator. His research show that the saturation level during 5 days of school implementation is high, and means the students during the learning process do not feel enjoy or bored learning with extended time or 5 days school. The contribution this article to this research is this research related to this research from the perception about full day school or 5 days school and the differences of this research compare with research from the researcher they are the subject is academic civitas, the object is only the students and this research use mix method with sequential explanatory as a model data analysis.

Another study was conducted by Rahmah (2017), who analyzed the students' perception towards the full day school system. Her study aims to determine the perception of students to the implementation of full day school, the obstacles and effort made of the school. The sample of the study was determined as many as 102 student people were taken using proportional random sampling. Data were collected by interview method and analyzed descriptively. The result showed that the perception of the students to the implementation of the full day school in MTs Mardhatillah Singaraja Academic year 2017/2018, predominantly indicates the agreed category. The problem that the students find sometimes feel bored and less concentrated on learning all day, students feel burdened with Homework (PR) provided by the teacher at the end of the lesson, the teacher should have to make more learning material because of the duration is longer, and also make a creative learning and fun activity or learning. The contribution of this research for this research gives different result or view from the setting of this research and the setting of this research also in Singaraja but the school is different and the differences of this research compare with the current researchthey are in the setting of the research, the object is only the students and the second is the subject is not in senior high school students but elementary-high school.

Study of Akhirah (2017) who analyzed the students' perception towards the implementation of full day school system, reviewed from the students' learning motivation. This study aimed to find out the perception of students who have high learning motivation towards the implementation of Full Day School system in class XI students of Building Engineering Study Program at SMK 10 Makassar. The second is the perceptions of students who have low learning motivation towards the implementation of Full Day School system in students class XI of Building Engineering Study Program at SMK 10 Makassar. The last is the differences in perceptions of students who have high learning motivation and students who have low learning motivation towards the implementation of the Full Day School system in class XI students of Building Engineering Study Program at SMK 10 Makassar. This type of research used is quantitative research with a comparative approach. The results of her study showed that the first is students who had high learning motivation had a good perception of the implementation of a full day school system, The second is students who had low learning motivation had poor perceptions of the application of full day school systems, The third is there were differences perceptions of students who have high learning motivation and students who have low learning motivation towards the implementation of full day school systems in class XI students of Building Engineering Study Program at SMK Negeri 10 Makassar, which are better students who have high learning motivation. The contribution of this research shows the students' motivation about the study with program full day school and the differences of this research compare with the current research is the subject of the research in which this study used students in vocational high school Negeri 10 Makasar, the object is only the students and the subject is the students' perception in terms of motivation and also the method used here is quantitative research with a comparative approach.

Kristiawan \& Tobari 2017) were conducted research on analyzing the characteristics of the Full Day School-Based Elementary School" this study was an inductive-qualitative research case study. From this study used some instruments, the instruments in this study were interviews, observation, and documentation about research news, research results, and theories related to the characteristics of the school-based full day school at the elementary level. The materials were studied in this study were notes, transcripts, books, newspapers, magazines, and websites. The results obtained indicate that full-day school at the primary level has applied "Integrated Curriculum". The objective of a full-day school program is that students can make more progress in terms of learning which will certainly have a positive impact on them. The contribution of this research compare with the current research is on giving information about how full day school works in elementary school. Other differences of this research 
compare with the current research is on the object, this research is used the elementary school as the research object, the object is only the students, the subject is the characteristic of full day school and this research is inductive-qualitative.

Ningsih (2016) conducted research on analyzing the relationship between the implementation of full day school and boarding school with character-building on eleventh-grade students. The aims of her research are to find out whether there is a correlation between the implementation of full day school toward forming character at the XI grade students of MAN 1 Surakarta in the academic year 2016/2017. The second one is knowing whether there is a correlation between the implementation of boarding school toward forming character at the XI grade students of MAN 1 Surakarta in the academic year 2016/2017. The third one is finding out whether a correlation between the implementation of full day school and boarding school toward forming character at the XI grade students of MAN 1 Surakarta in the academic year 2016/2017. A population of this research is the XI grade students of MAN 1 in the academic year 2016/2017, 30 students. A technique of sample is proportional random sampling. A technique of collecting data is through a questionnaire. it is used to obtain the data in terms of full day school, boarding school, and forming and character. In this research, validity found is external validity and the reliability is internal validity. A technique of analyzing the data used is the double correlation technique. In her research finding shows that Fcount is 8,96 it is consulted with Ftable with a significant level is 3.33. this, hypothesis stating that there is a correlation between the implementation of full day school and boarding school toward forming character at the XI grade of MAN 1 Surakarta in the academic year 2016/2017 is truly proven. The contribution of this research compare with current research is give the information about the character-building related to full day school program, and the differences of this research compare with the current research is on the object of the research, in which the object of this research is boarding school students, the object only the students and also the setting.

This study was different than previous studies because this study was conducted in two schools in northern Bali, namely SMAN 1 Singaraja and SMAN 4 Singaraja. Through seeing on the result from the previous studies, it can be seen that most of the results state that the perception in the schools is positive and this study can add more proof about the implementation of the full day school in Indonesia.

\section{Methods}

The design that is used in this research is qualitative research data analysis method. According to Sugiyono (2011), descriptive research is research that aims to provide or describe a situation or phenomenon that happen today by using scientific procedures to answer actual problems. This design helps researcher to plan and carry out studies, design to provide rich descriptive detail about people, place and other phenomena. This type of research is often associated with anthropology, sociology and psychology, but researchers in other fields, such as education, use it. In this study the researcher will describe the students' perception about an implementation of full day school in SMA N 1 Singaraja and SMA N 4 Singaraja, this study described the perception about Full Day School's implementation in SMA N 1 Singaraja and SMA N 4 Singaraja. The study was conducted in SMA N 1 Singaraja located in Pramuka Street N0.4. the reason of the researcher why choose this school because this school located in the center of Singaraja city and also as a model for another school to implement full day school program.SMA N 4 Singaraja located at Melati Street, Buleleng Regency, Bali,Indonesia which is near from SMA N 1 Singaraja who also follow the full day school program from the model school. The subjects in this research were collected from the population of the eleven grade students and teachers of SMA N 1 Singaraja and SMA N 4 Singaraja. Based on preliminary observation, the eleven grade students in SMA N 1 Singaraja and SMA N 4 Singaraja consist of eleven classes. In SMA N 1 Singaraja total were 343 students and in SMA N 4 Singaraja total were 347 students. The researcher used 60 students as the representative of the all eleven grade students at SMA N 1 Singaraja and SMA N 4 SingarajaThen, the teacher was chosen as the subject $10 \%$ from the total all of the teachers in SMA N 1 Singaraja and SMA N 4 Singaraja. The researcher used simple random sampling to sample the students. According to Arikunto (2010 as cited in Abidin and Purbawanto, 2015). The sampling must be taken based on minimum $10 \%$ from the population. In order to get a better understanding of how the data were obtained, the research procedure is presented in Table 3.1. :

Table 1. Research Procedure 


\begin{tabular}{|c|c|c|c|c|c|}
\hline No & $\begin{array}{l}\text { Research } \\
\text { Question }\end{array}$ & Procedure & Method & Instrument & Source \\
\hline 1 & $\begin{array}{l}\text { What are the } \\
\text { students' } \\
\text { perceptions } \\
\text { of the } \\
\text { implementati } \\
\text { on full day } \\
\text { school in } \\
\text { Buleleng } \\
\text { regency year } \\
2019 / 2020 ?\end{array}$ & $\begin{array}{ll}\text { 1. } & \text { Did observation } \\
\text { 2. } & \text { Did survey } \\
\text { 3. } & \text { Did data verification } \\
\text { 4. } & \text { Did conclusion }\end{array}$ & $\begin{array}{l}\text { 1. Observation } \\
\text { 2. Survey }\end{array}$ & $\begin{array}{l}\text { 1.Observation sheet } \\
\text { 2.Questionnaire }\end{array}$ & Students \\
\hline 2 & $\begin{array}{l}\text { What are the } \\
\text { teachers' } \\
\text { perceptions } \\
\text { of the } \\
\text { implementati } \\
\text { on full day } \\
\text { school in } \\
\text { Buleleng } \\
\text { regency year } \\
2019 / 2020 ?\end{array}$ & $\begin{array}{ll}\text { 1. } & \text { Did observation } \\
\text { 2. } & \text { Did survey } \\
\text { 3. } & \text { Did data verification } \\
\text { 4. } & \text { Did conclusion }\end{array}$ & $\begin{array}{l}\text { 1. } \\
\text { Observation } \\
\text { 2. Survey }\end{array}$ & $\begin{array}{l}\text { 1.Observation sheet } \\
\text { 2.Questionnaire }\end{array}$ & Teachers \\
\hline 3 & $\begin{array}{l}\text { What are the } \\
\text { strengths and } \\
\text { weaknesses } \\
\text { of the } \\
\text { implementati } \\
\text { on full day } \\
\text { school in } \\
\text { Buleleng } \\
\text { regency year } \\
2019 / 2020 \text { ? }\end{array}$ & $\begin{array}{ll}\text { 1. } & \text { Did observation } \\
\text { 2. } & \text { Did survey } \\
\text { 3. } & \text { Did interview } \\
\text { 4. } & \text { Did transcribing } \\
\text { 5. } & \text { Did data verification } \\
\text { 6. } & \text { Did conclusion }\end{array}$ & $\begin{array}{l}\text { 1. } \\
\text { Observation } \\
\text { 2.Survey } \\
\text { 3.Interview }\end{array}$ & $\begin{array}{l}\text { 1.Observation sheet } \\
\text { 2.Questionnaire } \\
\text { 3.Interview Guide }\end{array}$ & Teachers \\
\hline
\end{tabular}

After collecting the data, to present data to be easily understood, the data analysis that is used, on this steps is Analysis Interactive Models from Miles and Huberman, who divide the steps in data analysis activities with several parts, namely data collection (data collection), data reduction (data reduction), data presentation (data display), and conclusion or verification (conclutions). Data collection refers to the way conducted by researcher in order to gather all information or data related to the study. Here, the researcher will gather the information about the students' and teachers' perception about an implementation of full day school by conducting recording and give the students questionnaire. Data reduction means as the way to remove or reduce the data which is not related to the focus of the study. First of all, the researcher will transcribethe data, and then attempt to select only the data which was related to the study. If the researcher found the data which was not related to the study, in this casehow the students' perception and teachers' perception about an implementation of full day school, the researcher will remove the data. Data display which is also called as data presentation is the next step of analyzing data after the data reduction. Data display will organize the selected data in the data reduction in order to make conclusion. Data display typically can be presented in the form of table, chart, diagram and pictogram. In this study, the researcher will present the data in the form of table. For the table, the researcher will present about how the students' perception about an implementation of full day school. Then, the researcher drew conclusion and verify the results of the study after displaying the data of how the students' perception and teachers' perception about an implementation of full day school. In order to check the validity and reliability of the data, the researcher use triangulation method. According to Patton (1980) in Nafi'ah (2012) triangulation is amethod to improve the researcher comprehension of various reasoning about theconsistencies between two sets of data. It can be concluded that triangulation used toknow the consistency of the data that the researcher collects in certain period of time. According to Denzin in Mandagiri (2010), there are three types of datatriangulation that can be seen as follows:1) Time 
Triangulation, in this technique, the researcher collected the data about the student's perception at different time. In collecting the data about the students' perception and teachers' perception about an implementation of full day school in SMA N 1 Singaraja and SMA N 4 Singaraja, it was observed in different time, for example in differentdays in one until two months. Meanwhile, to know the students' perception and teachers' perception about an implementation full day school, the researchers interviewed the subjects of the study indifferent periods of time, for example in differentdays in one until two weeks. 2) Space Triangulation, in collecting the data by using space triangulation means observing thedata more than one site, for example in different class, By collecting the data in different spaces, the researcher gotclearer and more variations of the finding. 3) Person Triangulation, this technique means collecting the data more than one level of person.In this study, the researcher collected the data by observing and interviewingmore than one student of eleven grade in SMA N 1 Singaraja and SMA N 4 Singaraja. The result of all the data will be organize, will answer the research question which is about the students' perception and teachers' perception about an implementation of full day school.

\section{Result and Discussion}

This study was about investigating the students' and teacher's perceptions about the implementation of a full day school in SMAN 4 Singaraja and SMAN 1 Singaraja. Based on the result of the questionnaire from the student's perceptions, it could be seen that students have a positive perception of the implementation of full day school. It can be seen from the percentage from each question delivered to students in SMAN 4 Singaraja and SMAN 1 Singaraja. Most of the choices from students in SMAN 4 Singaraja and SMAN 1 Singaraja agree and very agree. This study was similar to previous studies such as Rahmah (2017) in which based on the result from Rahmah, the perception of the student to the implementation of full day school in MTs Mardhatillah Singaraja Academic year 2017/2018, predominantly indicates the agreed category. The result of this study was different from Triyono (2018) in terms of students' perception in which based on Triyono's previous research, the students during the learning process is not feel enjoy or bored learning with extend time or 5 days school.

While in the result of the questionnaire from the teacher's perception, it could be seen that teachers have a positive perception of the implementation of full day school. It can be seen from the percentage from each question delivered to the teacher in SMAN 4 Singaraja and SMAN 1 Singaraja. Most of the choices from the teacher in SMAN 4 Singaraja and SMAN 1 Singaraja agrees and very agree. This study was similar with previous studies such as Hardianti (2018) in which the result of the study was the teacher's perception of the application of full day school in general, the teacher agreed with the application in SMK 1 Pinrang because SMKN is a vocational school that uses a long time to conduct vocational practice and student behavior can be supervised during the school environment. The difference between this study with Hardinti's study can be seen from the second result from Hardianti in which the second is students' perceptions of the application of full day school at 1 Pinrang Vocational School in general, she found that the students did not agree because they felt tired, sleepy and bored so that class activities were not conducive and students' learning motivation decreased and students' rest periods were erratic.

Based on the explanation above, it can be concluded that 1) students' perception of SMAN 4 Singaraja and SMAN 1 Singaraja on the implementation of full day school is positive and 2) the teacher's perception of SMAN 4 Singaraja and SMAN 1 Singaraja on the implementation of the full day school is positive.

In terms of strengths and weaknesses, it can be seen that the strengths of full day school are full day school can develop the creativity of the students in terms of affective, cognitive, and psychomotor and the creativity of teachers in terms of teaching. It can be seen from the answer from the teacher from SMAN 1 Singaraja who said "Sistem full day school guru disini harus dapat menggembakan kreatifitas siwa dalam kegiatan pembelajaran melalui ranah afektif, kognitif dan psikomotor". It was also supported by a teacher in SMAN 4 Singaraja who said "Guru ya lebih dituntut untuk lebih kreatif lagi dalam mengajar siswa agar tidak bosan dan jenuh dengan waktu belajar yang panjang". This finding was in line with Kemendibud (2017) who stated that full day school program purpose to character building for the students and full day school developing the quality management of education the most important thing is full day school purpose to build character the students to have a good attitude and good moral of the students and teach them positive values. The weakness of full day school could be time management and teaching management in which the students could be bored because of additional hours of learning. It could be seen from the answer from the teacher of SMAN 4 Singaraja who said "Pengaturan jadwal dan juga memberikan materi yang bebobot dan juga penyampaian materi yang inovatif kepada siswa sehingga mereka tidak capek atau menggantuk pada saat jam pelajaran karena mereka sekolah dari pagi sampai sore". This finding is in line with Basuki (2008) who stated that full day school is a program that use half of 
time for school for learning in informal situation, not fully formal and enjoyable for the students and need creativity and innovation from the teacher

\section{Conclusion}

Based on the explanation and discussion in this study. It can be concluded that: 1) The students' perception on the implementation of Full Day School in SMAN 4 Singaraja and SMAN 1 Singaraja are categorized as positive. 2) The teachers' perception on the implementation of Full Day School in SMAN 4 Singaraja and SMAN 1 Singaraja are categorized as positive. 3) The strengths of full day school were developing teacher's creativity in terms of teaching and developing students' creativity in terms of affective, cognitive and psychomotor Based on the result of this study. It can be suggested that: 1) This study can be used as the guidance to conduct a further study which is relevant to this study. 2) This study can be used as a guide for the teachers to improve the the teaching method in the future to avoid the students feel bored in the class and stakeholders in the school to implement well-organized Full Day School.

\section{References}

Benawa, A., Peter, R., \& Makmun, S. (2018). The Effectiveness of Full Day School System for Students' Character Building. IOP Conference Series: Materials Science and Engineering, 288(1). https://doi.org/10.1088/1757-899X/288/1/012160

Hidayanti, M. (2017). Implementing Full Day School In Indonesi A: "Analys Ing Impacts On S Tudent, Teacher , And School Stakeholders ." (October), 236-243.

Kristiawan, M. (2017). The Characteristics of the Full Day School Based Elementary School. Transylvanian Review Cluj-Napoca Transylvanian Review Transylvanian Review, 5(14), 12-14.

Mendikbud. (2017). Permendikbud No 23 Tahun 2017. Mendikbud, (Juni 2017).

Nurkholis, I., Masrukhi, M., \& Juhadi, J. (2018). Full-day School Application and Its Effect on Character Building of Students (Case Study at Elementary School Nasima Semarang). Journal of Educational Social Studies, 7(2), 224-230.

Rahim, A. (2018). Full Day School Dalam Tinjauan Psikologi, Sosiologi, dan Ekonomi Pendidikan. AtTa'dib, 13(2), 104-114. https://doi.org/http://dx.doi.org/10.21111/at-tadib.v13i2.2376

Rahmah, A., \& Haris, I. A. (2019). Persepsi Siswa Terhadap Penerapan Sistem Full Day School Di Mts Mardhatillah Singaraja Tahun Ajaran 2017/2018. Jurnal Pendidikan Ekonomi Undiksha, 9(2), 407. Https://Doi.Org/10.23887/Jjpe.V9i2.20109

Yusuf, Y. (2017). Full Day School: School Excellence Model Implementation Process For A Good Education. Proc. Ictess UNISRI, 1(1), 305. 